\title{
Consumption Behavior of Organic Rice in Indonesia: Review of Modified Theory of Planned Behaviour
}

\author{
Nilawati Nasti $^{{ }^{*}} \quad$ Yuni Istanto $^{1}$ Anas Hidayat ${ }^{1} \quad$ Safrida $^{2}$ Siswoyo Haryono ${ }^{3}$ \\ 1.Doctoral Program, Faculty of Business and Economics, Universitas Islam Indonesia \\ 2.Faculty of Economics Universitas Islam Sumatera Utara, Indonesia \\ 3.Ph.D. in Management Program, Postgraduate Program, Universitas Muhammadiyah Yogyakarta
}

\begin{abstract}
This research aims to inspect the concept of the Theory of Planned Behavior (TPB) on organic rice consumption in Indonesia. This study uses a positivism research paradigm with a quantitative approach. The research sample includes families who consume organic rice in Indonesia. As many as 250 people. The analysis device used is Structural Equation Modeling (SEM), which operated through the AMOS v 24.0 program. The outcomes of this research are: (1) Knowledge of organic rice and income has a substantial effect on the attitude of organic rice consumption; (2) Income does not affect the intention to consume organic rice; (3) Income does not affect consumption behavior of organic rice; (4) The attitude of organic rice consumption has a significant effect on the intention to consume organic rice; (5) Subjective norms take a significant impact on intention to consume organic rice; (6) The choice to consume organic rice has a substantial effect on the consumption behavior of organic rice; (7) There is an indirect effect of knowledge about organic rice on organic rice consumption behavior with organic rice consumption attitude and organic rice consumption intention as mediating variables; (8) Income has a substantial effect on organic rice consumption behavior by mediating the attitude of organic rice consumption and intention to consume organic rice; (9) Subjective norms have an indirect effect on organic rice consumption behavior with the intention of consuming organic rice as a mediation. This study can be used in TPB modification by adding to the constructs of knowledge and income as factors that influence attitudes. In this study, payment does not directly affect the intention and consumption behavior of organic assuming.
\end{abstract}

Keywords: organic rice, attitudes, consumption intention, consumption behavior, subjective norms, knowledge and income

DOI: $10.7176 / \mathrm{EJBM} / 12-30-07$

Publication date:October $31^{\text {st }} 2020$

\section{Introduction}

This research built on the TPB theory developed by Fishbein (1975). TPB is the most comprehensive theory and is widely used to explain behavior (Chekima, 2015). Furthermore, TPB is a general model applied to expect and clarify differences in behavior (Watson et al., 2014). Buying behavior refers to consumer behavior, and purchase intention refers to consumption intention. TPB explains that when a person is faced with a choice to behave, he will start to reflect substitutes and assess based on the belief in his actions and impacts. Such thoughts will determine individual attitudes and ultimately influence the intention to behave (Chekima et al., 2015).

The first construct in TPB is attitude. Attitude is the extent to which an individual has an evaluation of one's judgment. TPB is widely accepted for evaluating consumer behavior. TPB is widely applied to predict consumer behavior (Gleim, 2013; Kim, 2011; Ritter, 2014; Yazdanpanah 2015), and is used to clarify the backgrounds of intention to buy organic hair care products, organic food, clothing, cleaning, and hygiene products, household appliances and other organic products.

The second construct in TPB is the subjective norm. This subjective norm mentions the social compression that felt in acting. Subjective norms mention the trust that an individual or group will agree to and care for certain behaviors (Ham, 2015). Subjective norms empirically influence the purchase intention of organic products significantly as research conducted by (Effendi, 2015; Humaira 2016; and Zibret, 2016). However, the results of other studies have found consistent results among subjective norms and intention to behave. Thus there is still a gap in the relationship between subjective norms and behavioral intention. This gap can be seen from the results of research by Gracia et al. (2010); Magistris (2012), (Ham et al., 2015).

The third construct in TPB is behavioral control, which in the TPB concept is called perceived behavioral control (PBC). According to Haque (2015), simply PBC can be understood as a condition or condition that allows a person to be able to manifest a behavior. Abrahamse's previous research (2019); Chen, (2017) once used income as an indicator of PBC, meaning that income can be used as a substitute for PBC. Households with high incomes can easily consume organic rice.

The results of research by Ramya (2016) state that one of the factors that influence purchasing behavior is income. The higher a person's income, the more positive the behavior of organic rice consumption will be. Organic rice tends to be more expensive than non-organic rice. Some researchers conclude that income can influence purchasing behavior (Humaira, 2016; Singh, 2017; Ruekkasaem, 2017). Someone who has a high income has a 
more significant opportunity to influence consumer behavior and also the intention to consume organic rice. Income is also predicted to affect attitudes towards organic rice consumption. The results of research conducted by (Aryal, 2009; Haghiri, 2009) prove that a person's income can influence attitudes. Therefore, this study integrates the two variables (knowledge and income) into the TPB framework as an antecedent of consumption intention and consumption behavior of organic rice.

In addition to emphasizing the variable subjective norm in the TPB, in this study, the construction of TPB did not use the original concept. However, it carried out two developments by adding variables that could affect attitudes, namely knowledge, and income. Research conducted by Smith (2010) proves that there is a substantial positive connection between knowledge and attitudes towards organic rice. Likewise, research was conducted by (Humaira, 2016; Maichum et al., 2017; and Singh, 2017). However, the results of research conducted by (Ahmad, 2015) prove the opposite where knowledge does not affect attitudes. Thus, good knowledge about organic rice is an essential factor that needs to be considered in this study because it can affect attitudes towards organic rice consumption.

In many studies, TPB has been proven as a concept capable of explaining behavior; in this case, the consumption behavior of organic rice. However, the TPB concept still needs to be further proven, especially regarding subjective norms that have not consistently influenced consumption intentions and consumption behavior of organic rice. Thus, organic knowledge and consumer income are considered equally important in consumption decisions for organic rice. Furthermore, income has been shown by many researchers to influence attitudes toward organic rice consumption.

\section{Literature Review and Hypothesis Development}

\subsection{Introduction}

\subsubsection{Theory of Planned Behavior (TPB)}

TPB is intended to forecast actual intentions and behavior. Two factors influence the TPB model, namely external and internal influences. External factors that predict actual behavior are subjective norms and perceived behavioral control. Meanwhile, internal factors that can be predictors of actual behavior are attitudes. Planned behavior connects attitudes, subjective norms, perceived behavioral control, and behavioral intention (Ajzen, 2015), which can be labeled as follows:

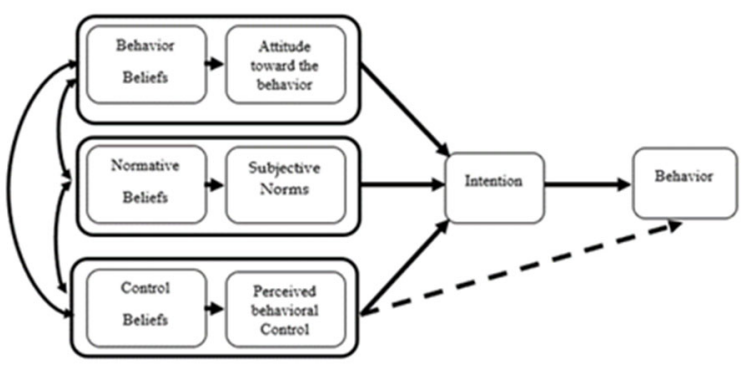

Figure 1. Theory of Planned Behavior (TPB).

\subsubsection{Buying (Consumption) Behavior of Organic Rice}

Consumer behavior theory, as a development of marketing concept, studies how persons, sets, and officialdoms take, purchase, habit goods, and services, concepts, or knowledge to see their wants and desires (Shih, 2015). Consumer purchasing behavior mentions to the choice, buying, and eating of goods and services to meet needs. Some factors can influence purchasing behavior according to Ramya, (2016), namely: culture, social, personal, income, and psychology.

\subsubsection{Purchase Intention (Consumption) of Organic Rice}

The intention is a motivational aspect that affects an individual's behavior; the sturdier the purpose of involving in the behavior, the more probable it is to behave. Rashid (2009) defines purchase intention as the possibility and readiness of an individual to consider buying a particular product. In this study, the intention is not only influenced by attitudes, subjective norms, and behavioral control, but also by income. The results of research conducted by (Yin, 2010) prove that income significantly affects purchase intention. Income in this study is a substitute for behavioral control. Income can affect the intention to consume organic rice.

\subsubsection{Attitudes Toward Behavior (Consumption) of Organic Rice}

Attitude toward the behavior, which is then only written as attitude, is the level to which an individual has a favorable assessment or not or an assessment of someone (Alam, 2011). The belief influences this attitude in the consequences of this behavior. A person's attitude towards objects has a structure consisting of three components, namely affective, cognitive, and conative (Azwar, 2016). In the context of this research, predictable attitudes can be influenced by knowledge and income. Organic knowledge is an essential issue because it represents the ability of customers to discriminate between organic (organic rice) or non-organic products and form a positive attitude 
towards organic products (organic rice) (Gracia, 2008).

2.1.5 Subjective Norms

Subjective norms refer to the trust that an individual or set of people must accept or care about certain behaviors (Ham et al., 2015). The influence of other people, such as family, close groups, colleagues, or job partners, can influence social compression about behavior (Paul, 2016). Some studies have reported that subjective norms are an essential element of intent to consume organic food (Al-Swidi, 2014; Effendi, 2015; Humaira, 2016; Zibret, 2016). Therefore, the subjective norm is an essential factor in encouraging the intention to consume organic rice.

2.1.6 Knowledge Regarding Organic Rice

Knowledge is an essential variable in consumer behavior and is influenced by information gathering. Knowledge of organic rice is defined as the capacity of the buyer to classify several ideas linked to organic rice through the data held by buyers. Knowledge influences the consumer's decision-making process. Li \& Li (2015) said that product knowledge is the buyer's perception of a particular creation, including earlier experience using the product. Several studies have shown that knowledge is positively and significantly related to attitude (Smith, 2010). Various research results prove that knowledge has a major effect on attitudes (Humaira, 2016; Maichum et al., 2017; and Singh, 2017).

2.1.7 Income

Income is the amount of income obtained from work, and usually, a person's income is calculated annually or every month. Thus income is a description of the economic position of the family in society (Hariningsih, 2008). Income in this study is applied as a substitute for PBC in the TPB concept. Research Abrahamse, (2019) and Chen, $\mathrm{Xu}, \&$ Day (2017) use income as a substitute for PBC. With high income, households can easily purchase organic rice. Besides affecting consumption intention and consumption behavior of organic rice, income is empirically proven to have a significant effect on attitudes. The results conducted by Aryal, (2009); Haghiri, (2009); Tsakiridou, (2008) proved that a person's income could influence attitudes.

\subsection{Hypothesis Development}

2.2.1 The Effect of Knowledge on Organic Rice and Income on Attitudes to Consumption of Organic Rice

Knowledge about organic rice plays a role in stimulating consumer attitudes towards organic products positively. Organic rice is a food product that is relatively good for health. Knowledge of organic rice will form a positive attitude toward organic rice. Various research results prove that knowledge has a significant influence on attitudes. As research conducted by Humaira (2016) and Maichum et al., (2017). Families with high incomes tend to form positive attitudes and buy more organic food. Research (Ramya, 2016) proves that one of the issues that affect attitude is income. From the study of the results of previous empirical and theoretical research, it is concluded that income is related to how they respond to the existence of organic rice to be consumed. Empirically and theoretically, hypotheses 1 and 2 are:

H1: Knowledge of Organic Rice has a Positive Effect on the Attitude of Consuming Organic Rice.

H2: Income Has a Positive Effect on Organic Rice Consumption

2.2.2 The Influence of Income, Attitudes and Subjective Norms on Intention to Consume Organic Rice

Someone who has a high income will have a more significant opportunity to consume organic rice so that they can determine their intention to consume organic rice. This positive attitude is getting more reliable because it is reinforced by high income. The outcomes of the study conducted by Rahnama (2016) prove that income significantly affects consumption intentions. Several studies have shown that attitudes influence purchase/consumption intentions (Humaira, 2016; Maichum et al., 2017; Singh, 2017; Zibret, 2016). Likewise, some researchers have also proven that subjective norms have a major effect on intention (Effendi et al., 2015; Humaira, 2016; Singh, 2017; and Žibret et al., 2018). There is no final decision that subjective norms can influence the intention to behave. Research conducted by (Gracia et al., 2010; Magistris, 2012) proves that subjective norms do not have a positive effect on intention. Empirically and theoretically, hypotheses 3, 4, and 5 are as follows:

H3: Income has a positive effect on the intention to consume organic rice

H4: The Attitude of Organic Rice Consumption Has a Positive Effect on the Intention of Consuming Organic Rice H5: Subjective Norms Have a Positive Effect on the Intention of Consuming Organic Rice

2.2.3 The Effect of Income, Intention on Organic Rice Consumption Behavior

Ramya (2016) states that one of the factors that influence consumer behavior is income. Income is essential for analyzing consumer behavior of organic rice because organic food is often more expensive than non-organic food. The advanced the income, the advanced the consumption of organic rice. Organic rice tends to be more expensive than non-organic rice. Several research results have proven that income can influence purchasing behavior (Humaira, 2016; Singh, 2017). The intention has a significant influence on purchasing/consumption behavior because the intention is the main predictor in the buying process. The outcomes of the study conducted by (Humaira, 2016; Maichum et al., 2017; and Singh, 2017) prove that the decision to make the prior intention very much determines a purchase, so empirically and theoretically the hypotheses 6 and 7 are as follows:

H6: Income Has a Positive Effect on Organic Rice Consumption Behavior 
H7: Intention of Organic Rice Consumption Has a Positive Effect on Organic Rice Consumption Behavior 2.2.4 Knowledge of Organic Rice Affects Organic Rice Consumption Behavior by Mediating the Attitudes of Organic Rice Consumption and Intention to Consume Organic Rice

Knowledge of organic rice is the capability of buyers to classify several ideas related to organic foods through the info that buyers have (Gracia, 2008). The results of the study (Singh, 2017; and Humaira, 2016) prove that attitudes and intentions can mediate the connection between knowledge and purchasing/consumption behavior. Thus empirically and theoretically, the following hypothesis 8 :

H8: Knowledge of Organic Rice has a Positive Effect on Organic Rice Consumption Behavior by Mediating the Attitudes of Organic Rice Consumption and Intention to Consume Organic Rice

2.2.5 The Effect of Income on Organic Rice Consumption Behavior by Mediating Organic Rice Consumption Attitudes and Organic Rice Consumption Intention

Income is another factor that is considered essential to influence the purchase of organic food (Paul, 2012). In the TPB concept, buying behavior is not directly formed but through attitudes and intentions. The intention is the greatest suitable part for expecting a person's behavior under various conditions, including purchasing organic rice. In line with that, Peter, (2010) agrees that purchase intention is a decided strategy to make an exertion to buy/consume a specific product. The results of research conducted by (Humaira, 2016; and Singh, 2017) prove that income has a direct effect on purchasing/consumption behavior. Attitudes and consumption intentions can be a link or a mediator between income and consumption behavior of organic rice. So empirically and theoretically, Hypothesis 9 is:

H9: Income Has a Positive Effect on Organic Rice Consumption Behavior by Mediating the Attitude of Organic Rice Consumption and Intention to Consume Organic Rice

2.2.6 The Influence of Subjective Norms on Organic Rice Consumption Behavior by Mediating Intention to Consume Organic Rice

Subjective norms as social norms are a person's belief that other people significantly influence certain behaviors (S. T. Wang, 2014). The results of research conducted by Smith, (2010); Vermeir, (2008) proves that subjective norms are a significant factor affecting consumer decision making in purchasing/consumption. The TPB concept, subjective norms, can influence purchasing/consumption behavior directly or through consumption intentions. The results of the study (Humaira, 2016; and Chu, 2018) prove that subjective norms affect buying/consumption behavior through intention. Thus consumption intention can facilitate the connection between subjective norms and consumption behavior. So empirically and theoretically, Hypothesis 10 is:

H10: Subjective Norms Have a Positive Effect on Organic Rice Consumption Behavior by Mediating the Intention of Consuming Organic Rice

\subsection{Research Framework}

Based on the development of the research hypothesis has been described above, the influence relationship between variables can be described as follows:

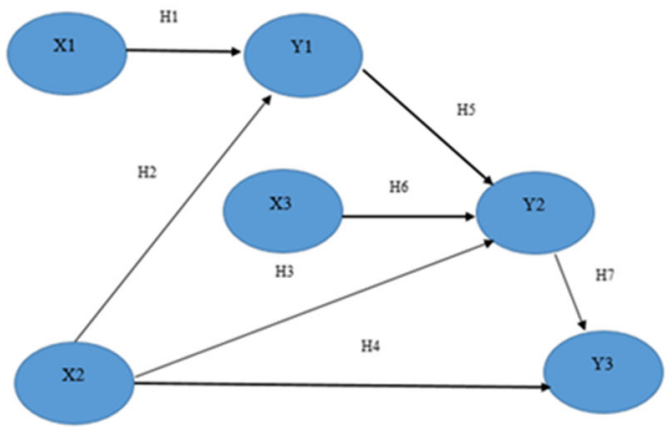

Figure 2. Research Framework.

Information: X1: Knowledge of Organic Rice, X2: Income, X3: Subjective Norms, Y1: Consumption Attitude of Organic Rice, Y2: Intention of Consuming Organic Rice and Y3: Consumption of Organic Rice.

\section{Research Method}

\subsection{Research Design}

The design of this study is quantitative, using the First Order Structural Equation Model (SEM) method. This research used a survey method to discover facts about the behavior of organic rice consumption in Indonesia. The population of this study was organic rice consumers in Indonesia who were selected from big cities representing the three regions of West, Central, and East Indonesia. Medan and Palembang represented West Indonesia, Central Indonesia was represented by DKI Jakarta, Bandung, Yogyakarta, Semarang and Surabaya, and Makassar 
represented eastern Indonesia. The sample was determined purposively, namely households that have consumed organic rice and the head of the household or homemakers. The desired sample was 287 samples, but the sample collected was only 250 respondents. The number of 250 samples has met the adequacy of SEM analysis using online and offline techniques.

\subsection{Operational Definition of Variables}

The exogenous variables in the study were knowledge about organic rice, income, and subjective norms. Endogenous variables consist of the consumption behavior of organic rice. Meanwhile, the mediator variables are the attitude toward organic rice consumption and the intention to consume organic rice.

The definition of organic rice knowledge is the consumer's ability to identify several concepts or attributes of organic rice through the information they have, either from the benefits or the process. Knowledge of organic rice, according to Biswas, (2014), is measured by indicators: (a) differentiating organic and non-organic rice, (b) knowing the organic rice processing process, (c) knowing the organic rice content, (d) knowing where organic rice is obtained, (e) know that organic rice is good for health, and (f) know that organic rice has something to do with the environment.

The definition of income is the amount of income obtained from work, and usually, a person's income is calculated annually or every month (Samuelson, 2002). Income indicators: (a) prefer to consume organic rice, (b) can set aside a portion of the income to consume organic rice, (c) the price is not a problem, (d) does not affect the purchase of other necessities, and (e) the income is more than sufficient consume organic rice every month.

The definition of subjective norms is a view that is considered necessary by someone who advises individuals to do or not do certain behaviors and motivations (Ham et al., 2015). Subjective norms are measured by Singh's approach, (2017): (a) suggestions from close friends, (b) family encouragement (c) recommendations from nutritionists/health experts, (d) recommendations from relatives, and (e) recommendations from community leaders.

The definition of attitude is an individual's reaction to an object in his environment; in this study, the object is organic rice (Nature, 2011). Indicators measure attitude variables in this study: (a) a good idea, (b) safe for consumption, (c) not durable, (d) has many benefits, (e) is natural, (f) has a positive impact on health.

The definition of consumption intention is a combination of consumer beliefs and attitudes towards products and services. The intention to behave can also mean a situation where consumers tend to buy or consume certain products (Mirabi, 2015). Consumption intention in measured adopts the opinion by Sreen, (2018); and Sing, (2017), namely: (a) plan to consume, (b) enthusiasm, (c) plan to continue consuming, (d) seek information, (e) enthusiastically consume organic rice.

The definition of consumer behavior is a decision-making process, and the actions of people involved in consuming or buying products or services (Ramya, (2016). Consumption behavior indicators have indicators according to Felix, (2016), namely: (a) happy to consume organic rice, (b) participate in preserving the environment, (c) providing solutions to environmental problems, (d) a culture of healthy living patterns, (e) safe for health, (f) free of chemicals, and (g) more nutritious.

\subsection{Method of collecting data}

Data collection uses a questionnaire that is distributed to respondents via the google form application. The completed questionnaires were then tabulated for analysis using the AMOS 24.0 program. Then tested the validity and reliability using Confirmatory Factor Analysis (CFA). Criteria in determining an indicator are said to be valid if it has a loading factor $(\lambda) \geq 0.7$. The criteria used to determine the level of instrument reliability is to construct reliability. A good instrument is one that has a construct reliability value $>0.7$ (Ferdinand, 2014). The full SEM model diagram is shown in Figure 3.

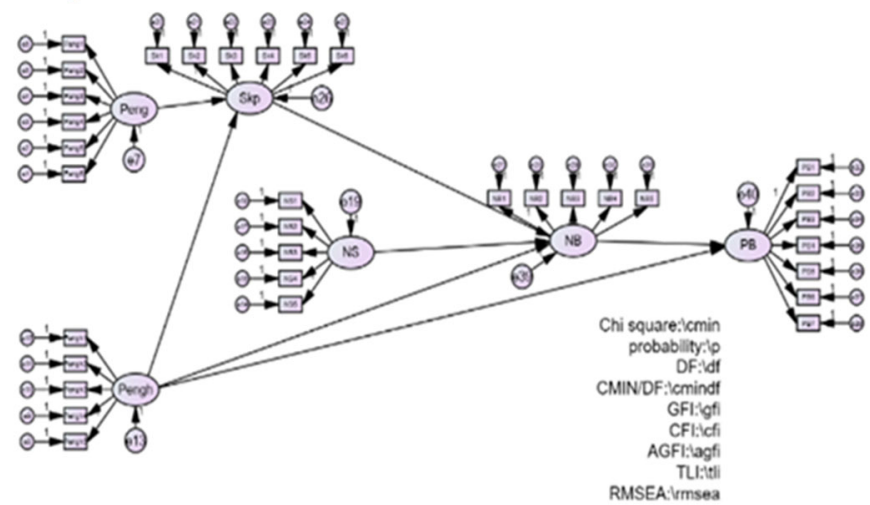

Figure 3. Full Model SEM Diagram. 


\section{Results and Discussion}

The following is the final result of the Goodness of Fit SEM test that has met the Goodness of Fit SEM criteria. All indicators of the fit model have been met, and the model is free from multicollinearity so that further testing can be carried out. From the structural analysis, the model fit indices are seen to be close to the acceptable fit, as shown in Table 1 below:

Table 1. Suitability of the Modified Full SEM model

\begin{tabular}{|l|l|l|l|}
\hline Criteria & Cut of value & Output & Kesimpulan \\
\hline$\chi^{2}$-Chi-square & 183.959 & 142.949 & Fit \\
\hline Probability & $\geq 0.05$ & 0.105 & Fit \\
\hline RMSEA & $\leq 0.08$ & 0.026 & Fit \\
\hline GFI & $\geq 0.90$ & 0.939 & Fit \\
\hline AGFI & $\geq 0.90$ & 0.916 & Fit \\
\hline CMIN/DF & $\leq 2.00$ & 1.162 & Fit \\
\hline TLI & $\geq 0.95$ & 0.991 & Fit \\
\hline CFI & $\geq 0.95$ & 0.993 & Fit \\
\hline
\end{tabular}

From the figure in table 1, it can be decided that the model is Fit because all elements, such as $\chi 2$-Chi-square, significance level, RMSEA, GFI, AGFI, CMIN / DF, TLI, and CFI, meet the requirements for Goodness of Fit. Results of the model evaluation show it has met the Goodness of Fit and also does not contain multicollinearity on the independent variables X1, X2, and X3). According to Gujarati \& Porter (2012), a model that has multicollinearity results in the regression coefficient generated in the research model being very weak, or it can provide unfavorable regression results. The multicollinearity test results show that the correlation X1 X2 is 0.418 , the correlation $\mathrm{X} 1$ à X3 is 0.363 , and the correlation X2 X3 is 0.263 . With these results, the correlation between the independent variables is smaller than 0.8 , so the research model does not contain multicollinearity..

\subsection{Hypothesis testing}

Based on the results of the calculation and testing of the direct effect, it can be found that the indirect effect and the total effect are as shown in the following table:

Table 2. Results of Calculation of Direct Effect, Indirect Effect and Total Effect

\begin{tabular}{|l|l|l|l|l|l|}
\hline \multirow{2}{*}{ Arah Pengaruh } & \multicolumn{2}{|l|}{ Koefisien Pengaruh } & \multicolumn{2}{l}{ Sig } & \multirow{2}{*}{ Kesimpulan } \\
\cline { 2 - 5 } & Langsung & Tidak Langsung & Total & & \\
\hline $\mathrm{X} 1 \rightarrow \mathrm{Y} 1$ & 0.459 & - & - & 0.001 & Accepted \\
\hline $\mathrm{X} 2 \rightarrow \mathrm{Y} 1$ & 0.220 & - & - & 0.001 & Accepted \\
\hline $\mathrm{X} 2 \rightarrow \mathrm{Y} 2$ & 0.141 & - & - & 0.064 & Rejected \\
\hline $\mathrm{X} 2 \rightarrow \mathrm{Y} 3$ & -0.071 & - & - & 0.143 & Rejected \\
\hline $\mathrm{Y} 1 \rightarrow \mathrm{Y} 2$ & 0.266 & - & - & 0.001 & Accepted \\
\hline $\mathrm{X} 3 \rightarrow \mathrm{Y} 2$ & 0.443 & - & - & 0.001 & Accepted \\
\hline $\mathrm{Y} 2 \rightarrow \mathrm{Y} 3$ & 0.826 & & & 0.001 & Accepted \\
\hline $\mathrm{X} 1 \rightarrow \mathrm{Y} 1 \rightarrow \mathrm{Y} 2 \rightarrow \mathrm{Y} 3$ & - & 0.106 & 0.106 & 0.001 & Accepted \\
\hline $\mathrm{X} 2 \rightarrow \mathrm{Y} 1 \rightarrow \mathrm{Y} 2 \rightarrow \mathrm{Y} 3$ & - & 0.187 & 0.083 & 0.001 & Accepted \\
\hline $\mathrm{X} 3 \rightarrow \mathrm{Y} 2 \rightarrow \mathrm{Y} 3$ & - & 0.477 & 0.477 & 0.001 & Accepted \\
\hline
\end{tabular}

4.1.1 Knowledge of organic rice has a positive effect on organic rice consumption attitudes

Table 2. shows that knowledge about organic rice has a significant effect on the attitude toward organic rice consumption because the significance level is $0.001<0.05$. This result shows that the advanced an individual knowledge about organic rice, the better his attitude in consuming organic rice. Magistris (2008) found that buyers who are knowledgeable about organic food will have a positive attitude towards organic food because they trust that organic food is more healthy and of higher quality than non-organic. The better a person's level of knowledge about something, it can shape consumer attitudes towards a product (Wang, 2019). Furthermore, Smith (2010) states that knowledge has a positive effect on attitudes about organic food. In this context, the attitude of consuming organic rice will be favourable if someone has good knowledge of organic rice. Knowledge of organic rice provides information about the unique brand attributes of the product and its benefits for consumers. In line with that, Engel (2005) states that knowledge is how consumers have absorbed much product information. If consumers have good enough knowledge about organic rice, the high price is not a problem for them.

4.1.2 Income has a positive effect on the attitude of consuming organic rice

Based on table 2, income has a significant effect on the attitude of organic rice consumption because the resulting significance level is $0.001<0.05$. The outcomes of this research support the research outcomes of Tsakiridou et al., (2008) and Rahnama (2016), which prove that income can affect consumer attitudes. The outcomes of this 
research also reinforce earlier research that higher incomes lead to better attitudes about organic food than those with low-income Tsakiridou et al., (2008). According to Tsakiridou et al., (2008), because someone with a high pay tends to seek information about organic products, even high-income consumers believe organic products have better quality and taste.

4.1.3 Income has a positive effect on the intention to consume organic rice

Based on table 2, income does not affect the intention to consume organic rice because the significance level is $0.064>0.05$. The non-impact of income on the intention to consume organic rice is in line with the outcomes of research by Omar, (2016); Sohel, Osman, (2015) also proved that income does not affect purchase intention. Hoang, (2006) conducted a study that showed that charge, salary, edification, oldness, and the number of kids significantly influenced consumer decisions to consume healthy vegetables. The difference in the results of this study may be due to different research objects, where this study focuses on organic rice, and Hoang's (2006) research focuses on vegetables as the object of research. These results indicate that income cannot be a direct predictor of the intention to consume organic rice, but income can shape intention through attitude. It is because someone with high income tends to seek information about organic products; even high-income consumers believe organic products have better value and a sense of taste (Tsakiridou et al., 2008).

4.1.4 Income has a positive effect on organic rice consumption behavior

Based on table 2, income does not affect organic rice consumption behavior, because the significance level is $0.143>0.05$. The outcomes of the study found that there was no significant effect of income on the consumption behavior of organic rice. The outcomes of this research are in line with the study conducted by (Loo et al., 2010) and (Shashikiran, 2015), which shows that income does not affect behavior. This study does not support the outcomes of the study, which states that income has a major effect on purchasing behavior (Humaira, 2016; and Singh, 2017). In theory, one of the factors that can determine purchasing behavior is the price included in the consumption behavior of organic rice. In Western countries, the fee of organic products is $50-200 \%$ higher than that of non-organic products. In Indonesia, it is also found that high prices cause people's reluctance to consume organic rice (Wijaya, 2014). The consumption behavior of organic rice is not determined by high or low income, but rather by the respondent's efforts to maintain health. It also shows that individuals are more inclined to seek the principle of benefits from organic rice compared to the sacrifices that will be incurred.

4.1.5 The attitude of organic rice consumption has a positive effect on the intention to consume organic rice

Based on table 2, the consumption attitude has a significant effect on the intention to consume organic rice because the significance level is $0.001<0.05$. The outcomes of this study support various research results that prove that attitudes influence intention (Singh, 2017; Humaira, 2016; and Zibret, 2016). The results of these studies prove that in order to raise people's intention to buy/consume organic rice, attitude is the main predictor. Thus, this study generally proves the concept in the TPB that attitudes can determine a person's consumption intention.

4.1.6 Subjective norms have a positive effect on the intention to consume organic rice

Based on table 2, the subjective norm has a significant effect on the intention to consume organic rice because the significance level is $0.001<0.05$. The outcomes of this study support the results of earlier studies (Al-Swidi, 2014; Effendi, 2015; Humaira, 2016; and Zibret, 2016). Subjective norms will be high if an individual believes that his family will benefit greatly from consuming organic food because it is healthier than non. It is by the opinion of Humaira, (2016) which states that subjective norms are a reflection of individual beliefs about how other people, who are considered essential to them, will see them involved in behavior. If the closest person wants or encourages someone to consume organic rice, the subjective norm will be higher. Subjective norms will be even higher if the motivation of someone to use organic rice is also high. The easy thing is if someone has motivation and encouragement from others about organic rice, the subjective norm will be higher.

4.1.7 The intention to consume organic rice has a positive effect on the behaviour of consuming organic rice Based on table 2, the attitude of organic rice consumption has a significant effect on organic rice consumption behavior because the significance level is 0.001 (less than $0.05<0.05$. The outcomes of this study support the various outcomes of research conducted by (Singh, 2017; Maichum et al., 2017); Humaira, 2016; Gracia, 2007; Wee, 2014). So it can be concluded that the intention largely determines the decision to make a purchase/consumption. The high intention to consume organic rice can ultimately determine consumption behavior. The outcomes of this research support a significant connection between intention and consumption of organic rice (A Tarkiainen, 2005).

4.1.8 The attitude of consuming organic rice and the intention to consume organic rice is a mediating effect between knowledge about organic rice and the behaviour of consuming organic rice

Based on table 2, the attitude of organic rice consumption and intention to consume organic rice can mediate the relationship between knowledge of organic rice and consumption behavior of organic rice because the significance level is $0.001<0.05$. The results of research conducted by (Singh, 2017; and Humaira, 2016) prove that attitudes and intentions can mediate the connection between knowledge and consumption behavior. Research conducted by Effendi, (2015), Humaira, (2016), Maichum et al., (2017) and Singh, (2017) proves that knowledge has a significant influence on attitudes. 
4.1.9 The attitude of organic rice consumption and the intention to consume organic rice is the mediating influences between income and consumption behaviour of organic rice

Based on table 2, the attitude towards organic rice consumption and the intention to consume organic rice can mediate the relationship between income and organic rice consumption behavior because the resulting significance level is $0.001<0.05$. These results also show that income cannot directly influence purchasing behavior, but must go through a mediator of consumer attitudes and intentions. In the TPB concept, buying behavior is not direct, but through attitudes and intentions. The outcomes of this research are consistent with the planned behavior theory, which postulates three independent determinants of intention, namely: attitudes toward behavior, subjective norms, and perceived behavioral control (Ajzen, 2002). These results are also consistent with Singh's (2017) findings, which show that positive consumer attitudes to organic products do not always interpret into the act. When someone with income does not directly influence the decision to consume, it can be seen from the results of hypotheses 3 and 4, which show that income does not influence the intention and behavior of consuming organic rice. However, hypothesis 2 proves that if income affects attitudes, it means that organic rice consumption behavior can be determined through attitudes and consumption intentions. It is because income in this study does not directly influence intention but through attitudes towards organic rice consumption.

4.1.10 The intention to consume organic rice is a mediating influence between subjective norms and consumption behaviour of organic rice

Based on table 2, the intention to consume organic rice can mediate the relationship between subjective norms on organic rice consumption behavior because the significance level is $0.011<0.05$. The outcomes of this research are in line with research by (Smith, 2010; Humaira, 2016; the Chu, 2018), proving that subjective norms affect consumption behavior through consumption intention. Thus subjective norms can influence consumer behavior if a person has the intention to consume organic rice, as Ajzen (1991) states that intention is a direct antecedent of behavior. So the subjective norm in this research can form the intention to consume organic rice because most consumers consume organic rice because of suggestions from relatives. Family encouragement is the main factor in consuming organic rice. This encouragement ultimately forms the intention to consume organic rice.

\section{Conclusions and Recommendations}

Based on the investigation of the results of the study and discussion, several conclusions can be drawn from the results of the research, including (1) Knowledge of organic rice has a significant effect on the attitude of organic rice consumption. Knowledge about organic rice, in the end, can foster a positive attitude towards organic rice consumption, (2) Income has a significant effect on the attitude of consuming organic rice. High-income consumers believe organic products are of better quality and taste. It means that income can determine how a person's attitude towards organic rice. (3) Income does not affect the intention to eat organic rice. The intention to eat organic rice is not determined by the level of income, but rather because of a positive attitude (organic rice is healthier and protects the environment). (4) Income does not affect the consumption behavior of organic rice. Respondents consume organic rice to maintain health so that income does not directly have a significant effect on organic rice consumption behavior, (5) Attitudes towards organic rice consumption have a significant effect on the intention to consume organic rice. The results of this study support the TPB concept that intention can be determined by attitude, (6) Subjective norms have a significant effect on the intention to consume organic rice. Family encouragement is the main factor and reason for respondents to consume organic rice. This phenomenon shows that there is a subjective norm in the behavior of consuming organic rice, (7) Intention of consuming organic rice has a significant effect on the behavior of consuming organic rice. The intention is a direct determinant of behavior. Someone who buys a particular product tends to have higher actual buying behavior than those who do not have the intention to buy, (8) The results of the study found that there was a significant indirect effect of knowledge about organic rice. Attitudes and intentions can be a mediator of the relationship between knowledge on organic rice consumption behavior, (9) Income have a significant effect on organic rice consumption behavior, which is mediated by organic rice consumption attitudes and organic rice consumption intentions. Attitudes are influenced by income, but income does not have a direct influence on behavior, meaning that income can only affect attitudes. However, attitudes are not always manifested by actual consumption behavior, (10) Subjective norms have a significant effect on organic rice consumption behavior mediated by intention consumption of organic rice. Subjective norms can lead to the growth of attitudes and strengthen the intention to carry out the behavior.

The results of this study were successful in contributing to the modification of TPB by adding to the constructs of knowledge and income as factors that influence attitudes. Knowledge in this study does not have a direct influence on consumer behavior but through attitudes and intentions. Income cannot influence consumption intention directly but through attitude. Likewise, the effect of income on consumption behavior is also indirect, but through attitudes and consumption intentions. 


\section{References}

Abrahamse, W. (2019). Encouraging pro-environmental behaviour: What works, what does not, and why. London: Elsevier Academic Press.

Ozaki, M., Adachi, Y., Iwahori, Y., \& Ishii, N. (1998). Application of fuzzy theory to writer recognition of chinese characters. International Journal of Modelling and Simulation, 18(2), 112-116

Ajzen, I. (1975). From intentions to actions: A theory of planned behavior. New York: Springer.

Ajzen, I. (2002). Perceived behavioural control, self-efficacy, locus of control, and the theory of planned behaviour. Journal of Applied Social Psychology, 32(4), 665-683

Ajzen, I. (2011). The theory of planned behaviour: Reactions and reflections. Journal Psychology \& Health, 26(9), $13-27$

Ajzen, I. (2015). Consumer attitudes and behaviour: The theory of planned behaviour applied to food consumption decisions. Rivista Di Economia Agraria, 70(2), 121-138

Ajzen, I. (1991). The Theory of Planned Behavior. Organizational Behavior and Human Decision Processes. Computer. 50(1), 179-211. https://doi.org/10.1016/0749-5978(91)90020-T

Alam, S. S., \& Sayuti, M. (2011). Applying the theory of planned behavior (TPB) in halal food purchasing. International Journal of Commerce and Management, 21(1), 8-20

Aliansi Organis Pertanian. (2017). Statistik pertanian organik indonesia Bogor: Aliansi Organis Indonesia.

Al-Swidi, A., Huque, M. R., Hafeez, M. H., \& Shariff, N. M. (2014). The role of subjective norms in the theory of planned behaviour in the context of organic food consumption. British Food Journal, 116(10), 1561-1580

Aryal, Kamal, P. P., Chaudhary, S., \& Pandit, G.. S. (2009). Consumers' willingness to pay for organic products: A case from kathmandu valley. The Journal of Agriculture and Environment, 10(1), 12-22

Askew, K. (2020). Organic Food's Coronavirus Boost: Health Crises Have a Long-term Impact on Consumer Demand. Computer. https:/www.foodnavigator.com/Article/2020/05/06/Organic-food-gets-coronavirusboost?utm_source $=$ copyright\&utm_medium $=$ OnSite\&utm_campaign $=$ copyright

Azwar, S. (2016). Sikap manusia teori dan pengukurannya. (2, Ed.). Yogyakarta: Pustaka Pelajar.

Biswas, A., \& Roy, M. (2014). Green products: an exploratory study on consumer behaviour in emerging economies of the east. Journal of Cleaner Production, 87(2), 463

Chekima, B. C., Wafa, S. K., Igau, O. A., Chekima, S., \& Sondoh, S. L. (2015). Examining green consumerism motivational drivers: Does premium price and demographics matter to green purchasing? Journal of Cleaner Production, 112, 3436-3450

Chen, C. F., Xu, X., \& Day, J. K. (2017). Thermal comfort or money-saving? Exploring intentions to conserve energy among low-income households in the united states. Energy Research \& Social Science, 26(2), 61-71

Chu, K. M. (2018). Mediating influences of attitude on internal and external factors influencing consumers' intention to purchase organic foods in China. Sustainability (Switzerland), 10(12), 1-15

Effendi, I., Ginting, P., Lubis, A. N., \& Fachruddin, K. A. (2015). Analysis of consumer behavior of organic food in north Sumatra Province, Indonesia. Journal of Business and Management, 4(1), 44-58

Eid, W. (2018). Integrating the theory of planned behaviour to identify determinants of halal food consumption in Japan. International Journal of Islamic Marketing and Branding, 3(3)

Engel, J. F., Roger, D. B., \& Paul, W. M. (2005). Consumer behavior. Forth Worth: Dreyden Press.

Felix, R., \& Braunsberger. (2019). I believe, therefore, i care the relationship between religiosity, environmental attitudes, and green product purchase in Mexico. International Marketing Review, 33(1), 137-155

Ferdinand, A. (2014). Structural equation modelling dalam penelitian manajemen. Semarang: FE UNDIP.

Fishbein, M., \& Ajzen, I. (1975). Belief, attitude, intention, and behavior: an introduction to theory and research. Reading: Addison -Wesley.

Gleim, M., Smith, J., Andrews, D., \& Cronin, J. (2013). Against the green: A multimethod examination of the barriers to green consumption. Journal of Retailing, 89(1), 44-61

Gracia, A., \& Magistris, D. T. (2008). The demand for organic foods in the south of Italy: A discrete choice model. Food Policy, 33(2), 386-396

Gracia, A., Magistris, T. D., \& Hurlé, B. (2010). Why do we buy organic? Integrating knowledge, attitudes and concerns in a simultaneous equation model for spanish consumers. Paper Prepared for Presentation at the 119th EAAE Seminar 'Sustainability, 2(1), 1-16

Haghiri, M., Hobbs, J. E., \& McNamara, M. L. (2009). Assessing consumer preferences for organically grown fresh fruit and vegetables in eastern New Brunswick. International Food and Agribusiness Management Review, 12(4), 81-100

Ham, M., Jeger, M., \& Ivković, A. F. (2015). The role of subjective norms in forming the intention to purchase green food. Economic Research-Ekonomska Istrazivanja, 28(1), 738-748

Haque, A., Sarwar, A., Yasmin, F., Tarofder, A. K., \& Hossain, M. A. (2015). Non-muslim consumers' perception of purchasing halal food products in Malaysia. Journal of Islamic Marketing, 6(1), 133-147

Hariningsih, E., \& Simatupang, R. A. (2008). Faktor-faktor yang mempengaruhi kinerja usaha pedagang eceran 
studi kasus: pedagang kaki lima di kota Yogyakarta. Jurnal Bisnis \& Manajemen, 4(2), 12-24

Humaira, A., \& Hudrasyah, H. (2016). Factors influencing the intention to purchase and actual purchase behavior of organic food. Journal of Business and Management, 5(4), 581-596

Kim, H., \& Chung, J. E. (2011). Consumer purchase intention for organic personal care products. Journal of Consumer Marketing, 28(1), 40 - 47

Magistris, T. D., \& Gracia, A. (2008). The decision to buy organic food products in southern Italy. British Food Journal, 110(9), 929-947

Magistris, T. D., \& Gracia, A. (2012). Do consumers pay attention to the organic label when shopping organic food in Italy? Organic Food and Agriculture. 1(2), 109-128

Maichum, K., Parichatnon, S., \& Peng, K. (2017). Developing an extended theory of planned behavior model to investigate consumers' consumption behavior toward organic food: A case study in Thailand. International Journal of Scientific \& Technology Research, 6(01), 72-80

Mirabi, V., Akbariyeh, H., \& Tahmasebifard, H. (2015). A study of factors affecting on customers purchase intention case study: The agencies of bono brand tile in Tehran. Journal of Multidisciplinary Engineering Science and Technology, 2(1), 267-273

Paul, J., Modi, A., \& Patel, J. (2016). Predicting green product consumption using the theory of planned behaviour and reasoned action. Journal of Retailing and Consumer Services, 123-134

Rahnama, H. (2016). Effect of consumers' attitude on buying organic products in Iran. Journal of Food Products Marketing, 22(3), 381-397

Ramya, N., \& Ali, M. (2016). Factors affecting consumer buying behaviour. International Journal of Applied Research, 2(10), 76-80

Rana, J., \& Paul, J. (2012). Consumer behaviour and purchase intention for organic food: A review and research agenda. Journal of Retailing and Consumer Services, 38(1), 157-165

Rashid, N. R. N. A. (2009). Awareness of eco-label in Malaysia green marketing initiative. International Journal of Business and Management., 4(8), 132-14

Ritter, A., Borchardt, M., Vaccaro, G.. L., Pereira, G.., \& Almeida, F. (2014). Motivations for promoting the consumption of green products in an emerging country: Exploring attitudes of Brazilian consumers. Journal of Cleaner Production, 106, 507-520

Ruekkasaem, L., \& Sasananan, M. (2017). The factors affecting decisions to purchase rice and consumer perception of organic rice in Bangkok, Thailand. International Jurnal of Advances in Agricultural \& Environmental Engg, 4(1)

Samuelson, P. A., \& Nordhaus, W. D. (2002). Ilmu makroekonomi. Jakarta: PT. Media Global Edukasi

Shashikiran, L., \& Madhavaiah, C. (2015). Impact of socio-economic factors on purchase behaviour of organic food products. International Journal of Economics and Business Administration, 1(2), 82-86

Shih, S. P., Yu, S., \& Tseng, H. C. (2015). The study of consumers' buying behavior and consumer satisfaction in beverages industry in Tainan, Taiwan. Journal of Economics, Business and Management, 3(3), 391-394

Singh, A., \& Verma, P. (2017). Factors influencing indian consumers' actual buying behaviour towards organic food products. Journal of Cleaner Production, 167, 473-483

Smith, Samantha, \& Paladino, A. (2010). Eating clean and green? Investigating consumer motivations towards the purchase of organic food. Australasian Marketing Journal, 18(2), 93-104

Sreen, N., Purbey, S., \& Sadarangani, P. (2017). Impact of culture, behaviour and gender on green purchase intention. Journal of Retailing and Consumer Services, 41(1), 177-189

Tarkiainen, Anssi, \& Sundqvist, S. (2005). Subjective norms, attitudes and intentions of finnish consumers in buying organic food. British Food Journal, 107(11), 808-822

Tsakiridou, E., Boutsouki, C., Zotos, Y., \& Mattas, K. (2008). Attitudes and behaviour towards organic products : An exploratory study. International Journal of Retail \& Distribution Management, 36(2), 158-175

Vermeir, I., \& Verbeke, W. (2008). Sustainable food consumption among young adults in Belgium: Theory of planned behaviour and the role of confidence and values. Ecol Econ, 64(2), 542-553

Wang, S. T. (2014). Consumer characteristics and social influence factors on green purchasing intentions. Marketing Intelligence and Planning, 32(7), 738-753

Wang, X., Pacho, F., Liu, J., \& Kajungiro, R. (2019). Factors influencing organic food purchase intention in Tanzania and Kenya and the moderating role of knowledge. Sustainability (Switzerland), 11(1)

Watson, M. C., Johnston, M., Entwistle, V., Lee, A., Bond, C., \& Fielding, S. (2014). Using the theory of planned behaviour to develop targets for interventions to enhance patient communication during pharmacy consultations for non-prescription medicines. International Journal of Pharmacy Practice, 26(6), 386-396

Wee, C. S., Ariff, M. S. B. M., Zakuan, N., \& Tajudin, M. N. M. (2014). Consumers perception, purchase intention and actual purchase behavior of organic food products. Society of Interdisciplinary Business Research, 3(2), 378-397

Wijaya, T. (2014). Nilai dan pengetahuan sebagai prediktor intensi beli makanan organik. Jurnal Manajemen Dan 
Kewirausahaan, 16(1), 69-81

Yazdanpanah, M., \& Forouzani, M. (2015). Application of the theory of planned behaviour to predict Iranian students' intention to purchase organic food. Journal of Cleaner Production, 107, 342-352

Žibret, M., Hafner-Fink, M., \& Kline, M. (2018). Testing an extended model of organic food purchasing behaviour. Teorija in praksa, 55(1), 180-198 